\title{
Study on HELLP syndrome - maternal and perinatal outcome
}

\author{
Lakshmi Narayana Kota*, Kavitha Garikapati, Prabha Devi Kodey, Gayathri K. B.
}

Department of Obstetrics and Gynecology, N R I Medical College and General Hospital, Chinakakani - 522503, Guntur Dist, Andhra Pradesh, India

Received: 13 December 2016

Accepted: 07 January 2017

\section{*Correspondence:}

Dr. Laxmi Narayana Kota,

E-mail: lakshminkota@gmail.com

Copyright: ( ) the author(s), publisher and licensee Medip Academy. This is an open-access article distributed under the terms of the Creative Commons Attribution Non-Commercial License, which permits unrestricted non-commercial use, distribution, and reproduction in any medium, provided the original work is properly cited.

\section{ABSTRACT}

Background: HELLP Syndrome is a serious obstetric complication in pregnancy characterised by haemolysis, elevated liver enzymes and low platelet count. Incidence is $0.5-0.9 \%$ of all pregnancies and in $10-20 \%$ of cases with severe preeclampsia and eclampsia. The aim of the study was to study the incidence, different clinical presentations and diagnosis of HELLP syndrome in Pre eclampsia and Eclampsia and to analyze the severity, complications, maternal and perinatal outcome.

Methods: It is a 16 months period retrospective study of 102 cases of preeclampsia and eclampsia admitted in NRIMC and GH in OBGY Department with more than 28 weeks gestation. Of these, 91 cases had preeclampsia and 11 cases had eclampsia. Out of these, 15 cases developed HELLP Syndrome. The available history, clinical data, detailed laboratory investigations were studied and categorized by Mississippi classification for better analysis of complications and outcome in HELLP syndrome.

Results: Of 91 cases of Preeclampsia, 12 cases (13.18\%) developed HELLP syndrome and out of 11 cases of Eclampsia, 3 cases $(27.27 \%)$ had HELLP Syndrome. Majority of the cases belonged to 21-25years age group and were mostly from lower Socio economic status. The present study showed $60 \%$ maternal morbidity and $6.6 \%$ maternal mortality and the perinatal morbidity and mortality was $46.6 \%$ each.

Conclusions: HELLP Syndrome is a severe variant and a dreadful complication of Preeclampsia and Eclampsia, it needs early diagnosis and timely intervention in the form of termination of pregnancy to arrest further progress of pathophysiology leading to complications.

Keywords: Abruption, HELLP Syndrome, IUFD, Pulmonary oedema, PRES, Peripartum hysterectomy, Retinal detachment, Stillbirth

\section{INTRODUCTION}

HELLP Syndrome term coined by Dr. Louis Weinstein in 1982 based on clinical features $\mathrm{H}$ (Hemolysis), EL (Elevated liver enzymes), LP (Low platelet count). ${ }^{1}$ It is a progressive and severe form of preeclampsia and eclampsia. It is classified according to criteria developed by University of Mississippi 2006, classification is based on platelet count nadir into class-I, class-II and class-III. ${ }^{2}$ The 3 variables are platelet count (PLT), Serum aspartate aminotransferase (AST), Serum alanine aminotransferase (ALT), Serum lactate dehydrogenase (LDH). The incidence of HELLP Syndrome in the present retrospective study is $14.7 \%(15 / 102$ cases $)$ which is comparatively higher, than in the study of Sowjanya et al $15.5 \%$ and $6.5 \%$ in the study of Ara $\mathrm{S}$ et al. ${ }^{3,4}$ The pathophysiology is vasospasm and endothelial dysfunction, fibrin deposition resulting in varied degree of hepatic ischemic damage, microangiopathic hemolytic anaemia and thrombocytopenia. HELLP Syndrome occurs in about $0.5-0.9 \%$ of all pregnancies and in 10$20 \%$ of cases with severe Preeclampsia and Eclampsia. HELLP Syndrome develops in about $70 \%$ cases before delivery, with a peak frequency between $27^{\text {th }}-37^{\text {th }}$ gestational weeks, $10 \%$ occur before the $27^{\text {th }}$ week, $20 \%$ beyond the $37^{\text {th }}$ gestational week . In the post partum 
period, HELLP Syndrome develops within the first 48 hours after delivery.

The onset of HELLP Syndrome is rapid, variable and sometimes atypical, so the diagnosis is generally delayed for 5-7 days. Many of them are misdiagnosed with disorders, like cholecystitis, oesophagitis, gastritis, hepatitis, viral fever or idiopathic thrombocytopenia. Typical clinical symptoms are right upper quadrant pain abdomen or epigastric pain, nausea and vomiting. Pain abdomen may be colicky, intermittent associated with malaise few days before actually diagnosing it to be HELLP Syndrome.

\section{METHODS}

This was a retrospective study done in NRIGH and MC, Chinakakani, Guntur District for a period of 16 months i.e., January 2015 to April 2016, including 102 cases of severe preeclampsia and Eclampsia, out of which 15 cases developed HELLP Syndrome.

\section{Inclusion criteria}

- Women with severe preeclampsia and Eclampsia $>28$ weeks with abnormal laboratory findings.

- Women with severe hypertension from more than 28 weeks gestation.

\section{Exclusion criteria}

- Women with less than 28 weeks gestation.

- Women with hypertension due to other than pre eclampsia and eclampsia.

- Women with other disorders like viral hepatitis, Gastroenteritis, cholecystitis and pancreatitis.

- Women with differential diagnosis of HELLP Syndrome like

i) Diseases related to pregnancy

a) benign thrombocytopenia of pregnancy

b) AFLP

ii) Infections and inflammatory diseases not specifically related to pregnancy
a) Viral hepatitis
b) Cholangitis
c) Cholecystitis
d) Upper UTI
e) Gastritis
f) Acute pancreatitis
iii) Thrombocytopenia

a) ITP b) Folate deficiency

c) SLE

d) APLA syndrome

iv) Rare diseases that may mimic HELLP Syndrome

a) TTP

b) HUS

The selected cases were studied with history, clinical data and detailed laboratory investigations done including complete haemogram, peripheral blood smear, coagulation profile, liver profile, renal profile values which have been recorded and HELLP Syndrome cases were classified according to Mississippi classification.

Table 1: Mississippi classification (University of Mississippi 2006 criteria).

\begin{tabular}{l} 
Mississippi classification \\
Class I \\
Platelet count $\leq 50,000 / \mathrm{mm}^{3}$ \\
Sr.AST or Sr. ALT $\geq 70 \mathrm{IU} / \mathrm{L}$ \\
Sr.LDH $\geq 600 \mathrm{IU} / \mathrm{L}$ \\
Class II \\
Platelet count $>50,000-\leq 100,000 / \mathrm{mm} 3$ \\
Sr.AST or $\mathrm{Sr}$. ALT $\geq 70 \mathrm{IU} / \mathrm{L}$ \\
Sr. LDH $\geq 600 \mathrm{IU} / \mathrm{L}$ \\
\hline Class III \\
Platelet count $>100,000$ to $\leq 150,000 / \mathrm{mm}^{3}$ \\
Sr.AST or Sr. ALT $\geq 40 \mathrm{IU} / \mathrm{L}$ \\
Sr.LDH $\geq 600 \mathrm{IU} / \mathrm{L}$ \\
\hline
\end{tabular}

Mississippi classification is based on platelet count Nadir: Class I -Less than 50,000 per cubic Millimeter; Class II $->50,000$ to less than $1,00,000$ per cubic millimeter; Class III $->1,00,000$ to $1,50,000$ per cubic millimeter.

\section{RESULTS}

In the present study of 102 cases, 91 were preeclampsia and 11 were eclampsia, which were analyzed retrospectively and 15 cases were diagnosed as HELLP Syndrome of which 12 cases were from preeclampsia and 3 cases were from Eclampsia.

According to Mississippi classification, 6 cases (50\%) of pre eclampsia developed class II and 2 cases $(66.6 \%)$ of Eclampsia developed class III.

Out of 15 cases of HELLP Syndrome, 12 cases $(80 \%)$ were referred cases from Primary health center, Community health center, Employee state insurance and other private nursing hospitals (Table 2).

$60 \%$ cases were in the age group of 21-25 years (Table $3)$. 
Table 2: No. of cases according to Mississippi classification.

\begin{tabular}{|lllll|}
\hline Total & Class I & Class II & Class III & Total \\
\hline Preeclampsia & $3(25 \%)$ & $6(50 \%)$ & $3(25 \%)$ & $12(80 \%)$ \\
\hline Eclampsia & 0 & $1(33.3 \%)$ & $2(66.6 \%)$ & $3(20 \%)$ \\
\hline
\end{tabular}

In present study, $54.5 \%$ of primigravidae had class II and about $75 \%$ of multi had class III Syndrome (Table 4). In our study, $11(73.3 \%)$ cases of HELLP SYNDROME were seen between 32-38 weeks gestation (Table 5). In our study, all 15 cases developed HELLP Syndrome in antenatal period.

Table 3: No. of cases according to age group.

\begin{tabular}{|lllll|}
\hline Age (years) & Class I & Class II & Class III & Total \\
\hline $15-20$ & 0 & 0 & 0 & 0 \\
\hline $21-25$ & 2 & 4 & 3 & 9 \\
\hline $26-30$ & 1 & 0 & 2 & 3 \\
\hline$>30$ years & 0 & 2 & 1 & 3 \\
\hline
\end{tabular}

Table 4: No. of cases according to gravida.

\begin{tabular}{|lllll|}
\hline Gravida & Class I & Class II & Class III & Total \\
\hline Primi & $2(18.1 \%)$ & $6(54.5)$ & $3(27.2 \%)$ & $11(73.3 \%)$ \\
\hline Multi & $1(25 \%)$ & 0 & $3(75 \%)$ & $4(26.6 \%)$ \\
\hline
\end{tabular}

The most commonly observed feature is dizziness - 5 cases $(33.3 \%)$, renal complications like oliguria, haematuria, renal failure - 3 cases $(20 \%)$. Fever, malaise, body pains - 1 case $(6.6 \%)$, Non specific symptoms 1 case $(6.6 \%)$.

Table 5: No. of cases according to gestational age.

\begin{tabular}{|lllll|}
\hline Gestational age (weeks) & No. of cases & Class II & Class III & Class III \\
\hline$>28-32$ & 2 & 1 & 1 & 0 \\
\hline$>32-38$ & 11 & 2 & 5 & 4 \\
\hline$>38$ & 2 & 0 & 0 & 2 \\
\hline
\end{tabular}

Table 6: No. of cases according to laboratory findings.

\begin{tabular}{|llllll|}
\hline AST & ALT $>70 / U / L$ & LDH & Sr. bilirubin & Sr. uric acid & $\begin{array}{l}\text { Sr. creatinine } \\
>70 I U / L\end{array}$ \\
\hline 15 & 15 & $11(73.3 \%)$ & $6(40 \%)$ & $>7 \mathrm{mg} / \mathrm{dll}$ & $>1.2 \mathrm{mg} / \mathrm{dll}$ \\
\hline
\end{tabular}

Table 7: No. of cases according to platelet Count by Mississippi classification.

\begin{tabular}{|llll|}
\hline Total No. of cases & Class I & Class II $(50,000$ to & class III $(>1,00000$ TO \\
\hline 15 & $\left(<50,000 / \mathrm{mm}^{3}\right)$ & $1,00000 / \mathrm{mm} 3)$ & $1,50000 / \mathrm{mm} 3)$ \\
\hline
\end{tabular}

According to the investigations, laboratories threshold that indicate more than $75 \%$ of severe maternal morbidity are LDH concentrations more than $1000 \mathrm{U} / \mathrm{L}$, Serum uric acid more than $7 \mathrm{mg} / \mathrm{dl}$, Serum creatinine more than 1.2 $\mathrm{mg} / \mathrm{dl}$, Serum bilirubin more than $2 \mathrm{mg} / \mathrm{dl}$, AST/ALT more than $70 \mathrm{IU} / \mathrm{L}$ (Table 6). 
Class I - 3cases (20\%) and class II and III account for 12 cases $(40 \%)$ each (Table 7$)$. Maternal morbidity in the form of Eclampsia, pulmonary edema, abruption PPH, Renal failure, pleural effusion, multiorgan failure etc. and 1 patient who underwent peripartum hysterectomy due to uncontrolled PPH and persistent, uncorrectable coagulopathy death occurred, on the whole $60 \%$ of maternal morbidity in 15 cases.

Table 8: Cases according to maternal outcome.

\begin{tabular}{|c|c|c|c|c|}
\hline Complications & $\begin{array}{l}\text { No. of } \\
\text { cases }\end{array}$ & $\begin{array}{l}\text { Class } \\
\text { I }\end{array}$ & $\begin{array}{l}\text { Class } \\
\text { II }\end{array}$ & $\begin{array}{l}\text { Class } \\
\text { III }\end{array}$ \\
\hline $\begin{array}{l}\text { Heart failure } \\
\text { Pulmonary edema }\end{array}$ & 1 & 1 & 0 & 0 \\
\hline Severe anaemia & 0 & 0 & 0 & 0 \\
\hline Abruption & 1 & 1 & 0 & 0 \\
\hline Abruption+PPH & 1 & 1 & 0 & 0 \\
\hline PPH+ Eclampsia & 1 & 0 & 0 & 1 \\
\hline Eclampsia & 1 & 1 & 0 & 0 \\
\hline $\begin{array}{l}\text { Multiorgan failure } \\
\text { DIC+ARF+ } \\
\text { Pulmonaryedema }\end{array}$ & $\begin{array}{l}5 \\
1\end{array}$ & 0 & 1 & 0 \\
\hline $\begin{array}{l}\text { Haematuria+B/L } \\
\text { Retinal } \\
\text { detachment }\end{array}$ & 1 & 0 & 1 & 0 \\
\hline $\begin{array}{l}\text { Oliguria+B/L } \\
\text { Pleural effusion }\end{array}$ & 1 & 0 & 1 & 0 \\
\hline $\begin{array}{l}\text { PPH+PRES+ } \\
\text { Eclampsia }\end{array}$ & 1 & 0 & 0 & 1 \\
\hline $\begin{array}{l}\text { Abruption+ } \\
\text { coagulopathy+ } \\
\text { peripartum } \\
\text { hysterectomy } \\
\text { maternal death }\end{array}$ & 1 & 0 & 1 & 0 \\
\hline
\end{tabular}

In 15 cases of HELLP Syndrome, 10 cases(66.6\%) developed various maternal complications, of which 5 cases had multiorgan failure out of which 1 case died of uncontrollable, persistent, uncorrectable coagulopathy with peripartum hysterectomy belonging to class II. Maternal morbidity is $60 \%$, and maternal mortality is $6.66 \%$.

10 cases $(66.6 \%)$ have average birth weight of $>1 \mathrm{~kg}$ $2.5 \mathrm{~kg}$ of which 5 belonged to class III. In present study, 2 term deliveries $(13.3 \%)$, of which 1 baby is alive and healthy and another is term IUFD. Preterm babies were $13(86.6 \%), 7$ of them were born alive with IUGR.

Total number of live births was $8 / 15(53.3 \%)$; of which 7 babies were preterm with IUGR $(46.6 \%)$ and 1 was term, healthy baby. The overall perinatal morbidity and mortality was $(46.6 \%)$ each. The perinatal mortality rate is comparatively more than in the study by Sowjanya et al (35.33\%). Birth asphyxia and prematurity were the commonest causes of perinatal mortality rates. In our study, $60 \%$ maternal morbidity seen, each class contributing $20 \%$. Maternal mortality was seen in class II with $6.66 \%$.

Table 9: Perinatal outcome.

\begin{tabular}{|lllll|}
\hline Complications & $\begin{array}{l}\text { Total } \\
\text { No. of } \\
\text { cases }\end{array}$ & Class I & $\begin{array}{l}\text { Class } \\
\text { II }\end{array}$ & $\begin{array}{l}\text { Class } \\
\text { III }\end{array}$ \\
\hline Term & 2 & 0 & 0 & 2 \\
\hline Preterm & 13 & 3 & 6 & 4 \\
\hline IUGR & 7 & 0 & 3 & 4 \\
\hline Birth asphyxia & 4 & 2 & 2 & 0 \\
\hline Still births & 2 & 0 & 1 & 1 \\
\hline MAS & 5 & 2 & 2 & 1 \\
\hline Low APGAR & 4 & 2 & 2 & 0 \\
\hline NICU & 6 & 2 & 2 & 2 \\
admissions & & 2 & & \\
\hline IUFD & 2 & 2 & 0 & 0 \\
\hline ND & 3 & 2 & 1 & 0 \\
\hline Oligamnios & 6 & 1 & 1 & 4 \\
\hline Anhydramnios & 1 & 0 & 0 & 1 \\
\hline
\end{tabular}

\section{DISCUSSION}

HELLP Syndrome is a life threatening complication, considered to be a severe variant of Preeclampsia and Eclampsia. The incidence of HELLP Syndrome in the present retrospective study is $14.7 \%$ (15/102 cases) which is comparatively higher, than in the study of Sowjanya et al $15.5 \%$ and $6.5 \%$ in the study of Ara $\mathrm{S}$ et al. ${ }^{3,4}$ This may be due to better laboratory facility and better interpretation of Sibai's diagnostic Criteria. Early identification of risk factors in pregnancy and timely intervention gives better maternal and perinatal outcome. In the study of 15 cases of HELLP Syndrome, 12 from pre eclampsia and 3 from eclampsia were analyzed. In 15 cases, only 3 cases $(20 \%)$ were booked comparable to $38.23 \%$ of booked cases of Ara $\mathrm{S}$ et al and $52.64 \%$ of Sowjanya et al studies, Sibai BM (21\%), Isler CM et al $32.8 \%$ and $47.36 \%$ (63 cases) were unbooked in the study. ${ }^{5,6}$ Our study had $12(80 \%)$ referral cases. 11 cases (73.3\%) belonged to Primi gravida and 4 cases (26.6\%) belonged to multi parous women.

All 15 cases (100\%) were antepartum which was comparatively higher than in of Ara S et al $75 \%$ and majority, 11 cases $(73.3 \%)$ of them were between $>32$ and 38 gestational weeks comparable to Vigil-de Gracia $\mathrm{P} 40 \% .^{7}$ In all these cases studied, 2(13.3\%) were delivered vaginally and 13 cases $(86.6 \%)$ were delivered by caesarean section. The main complications were DIC, renal failure, pulmonary edema, pleural effusion, PRES retinal detachment, abruption, multi organ failure, PPH, eclampsia. The outcome of HELLP Syndrome depends on the severity, timely intervention, availability of tertiary care facilities like ICU, dialysis, ventilatory support and equipment and availability of blood and blood products. 
In this study, 9 cases $(60 \%)$ needed intensive care management; of which 8 cases were discharged home healthy and 1 case death occurred. All 9 cases (60\%) were treated with FFP, platelet transfusion and other blood products.
In the present study, the maternal mortality was 1 $(6.66 \%)$ because of late referral in bad condition. It is comparable to Sibai $\mathrm{BM}$ et al $(1.8 \%)$, Isler $\mathrm{CM}$ et al (7.8\%), Vigil-de Gracia P (2.3\%), Sowjanya et al (4.5\%), Magann EF et al (23.2\%), Visser W et al (14.1\%). ${ }^{6-8,10}$

Table 10: Maternal and perinatal outcome.

\begin{tabular}{|lllll|}
\hline Outcome & Total & Class I & Class II & Class III \\
\hline Maternal morbidity & $9 / 15(60 \%)$ & $3 / 15(20 \%)$ & $3 / 15(20 \%)$ & $3 / 15(20 \%)$ \\
\hline Maternal mortality & $1 / 15(6.66 \%)$ & -- & $1 / 15(6.66 \%)$ & -- \\
\hline Perinatal morbidity & $7 / 15(46.66 \%)$ & -- & $3 / 15(20 \%)$ & $4 / 15(26.6 \%)$ \\
\hline Perinatal mortality & $7 / 15(46.66 \%)$ & $3 / 15(20 \%)$ & $3 / 15(20 \%)$ & $1 / 15(6.66 \%)$ \\
\hline
\end{tabular}

The perinatal deaths were 7 cases $(46.6 \%)$ comparable to Sibai BM(33.3\%), Magann EF et al (23.2\%), Liu et al (42\%), Visser W (14.1\%), Sowjanya et al 35.33\%..$^{8-10}$ The main cause for perinatal deaths in OUR study was prematurity $(86.6 \%)$ comparatively higher than in Ara S $49.62 \%$, Sowjanya et al $35.33 \%$ followed by birth Asphyxia .The still birth rate in the present study was 2 cases $(13.33 \%)$. Expectant management, appropriate intervention, NICU facility will improve the perinatal outcome. In our present study, vaginal delivery was done in 2 cases as they were in labour. In 13 cases, active management was taken in the form of termination of pregnancy by caesarean section irrespective of gestational age as delivery is the definitive management to prevent further complications and to save the mother. Caesarean section rate in the present study was 13 cases $(86.6 \%)$. It is comparable to $71 \%$ of Vigil-de Gracia P, $63 \%$ Hadded $\mathrm{O}$ et al. ${ }^{7,11}$

\section{CONCLUSION}

Early registration and regular antenatal checkups play a major role in early diagnosis and classification of HELLP Syndrome. Availability of better transport facilities and prompt referral is essential. HELLP Syndrome must be treated in tertiary care center as it is one of the dreadful obstetric complication which needs multidisciplinary team approach, availability of life saving facilities like mechanical ventilators, dialysis equipment and blood products neonatal care facilities. For this reason, obstetrician at any level should be attentive, alert and need to improve quality care and make efforts for early identification even at its atypical presentation and should be able to provide skilled management techniques till the case is shifted to tertiary care center. The Global mortality rate of HELLP Syndrome has been reported to be as high as $25 \%$. That's why it is critical for expecting mothers to be aware of the condition and its symptoms, so they can receive early diagnosis and treatment. Doctors should enhance their skills in antenatal care to identify high risk factors at primary health centre and community health centre.
Funding: No funding sources

Conflict of interest: None declared

Ethical approval: The study was approved by the Institutional Ethics Committee

\section{REFERENCES}

1. Weinstein L. Syndrome of hemolysis, elevated liver enzymes and low platelet count: severe consequences of hypertension in pregnancy. Am J Obstet Gynecol. 1982;142:159-67.

2. Martin JN, Rose CH, Briery CM. Understanding and managing HELLP Syndrome: the integral role of aggressive glucocorticoids for mother and child. Am J Obstet Gynecol. 2006;195(4):914-34.

3. Sowjanya K, Bhavani. Clinical Study on HELLP Syndrome - Maternal and Perinatal Outcome. IOSR Journal of Dental and Medical Sciences. 2016;15(1):71-6.

4. Ara S, Singh BB. Incidence of HELLP Syndrome in pre-eclampsia and eclampsia and Maternal and Perinatal outcome including Morbidity and Mortality. Indian Journal of Research. 2015;4(7).

5. Sibai BM, Ramadan MK, Chari RS, Friedman SA. Pregnancies complicated by HELLP Syndrome: subsequent pregnancy outcomes and long term prognosis. Am J Obstet Gynecol. 1995;172(1 Pt 1):125-9.

6. Isler CM, Rinehart BK, Terrone DA. Maternal mortality associated with HELLP Syndrome. Am J Obs Gyn. 1999;181:924.

7. Vigil-De Gracia P. Pregnancy complicated by pre eclampsia-eclampsia with HELLP Syndrome. International Journal of Gynecology and Obstetrics. 2001;72(1):17-23.

8. Martin JN Jr, Rinehart BK, May WL, Magann EF, Terrone DA, Blake PG. The spectrum of severe pre eclampsia: comparative analysis by HELLP Syndrome classification. Am J Obstet Gynecol. 1999;180(6 Pt 1):1373-84. 
9. Liu CM, Chang SD, Cheng PJ, Chao AS.. Comparisons of maternal and perinatal outcomes in Taiwanese women with complete and partial HELLP Syndrome and women with severe Pre eclampsia without HELLP. J Obstet Gynaecol Res. 2006;32(6):550-8.

10. Visser W, Wallenburg HCS. Temporising management of severe pre eclampsia with and without the HELLP Syndrome. British Journal of Obstet and Gynecology. 1995;102:111-7.
11. Bassam H, Barton JR, Livingston JC. Risk factors for adverse maternal outcomes among women with HELLP Syndrome. Am J Obstet Gynecol. 2000;183:444.

Cite this article as: Lakshmi NK, Kavitha G, Prabha Devi K, Gayathri KB. Study on HELLP syndrome maternal and perinatal outcome. Int $\mathrm{J}$ Reprod Contracept Obstet Gynecol 2017;6:714-9. 